\title{
DIFFERENCES AND MUTUAL CONNECTIONS OF THE TRANSPORT SAFETY SYSTEMS
}

\author{
ODRĘBNOŚCI I WZAJEMNE POWIĄZANIA \\ SYSTEMÓW BEZPIECZEŃSTWA TRANSPORTU
}

\begin{abstract}
Lech Michalski
Department of Highway Engineering, Faculty of Civil Engineering and Environment, Gdansk University of Technology, ul. Narutowicza 11, 90-952 Gdansk, Polska Katedra Inżynierii Drogowej, Wydział Inżynierii Lądowej i Środowiska, Politechnika Gdańska, ul. Narutowicza 11, 90-952 Gdańsk, Polska

e-mail: michal@pg.gda.pl
\end{abstract}

\begin{abstract}
Each day in the world's transport system there are more than 3 thousand fatalities; most of them die in road accidents. From the point of view of the safety management, each of the branch systems is organized differently. The differences concern data bases, institutions managing the transport infrastructure and studying the accidents, systems monitoring the traffic of vehicles, trains and ships. Despite many differences in the functioning of particular branches of transport, there are potentially big possibilities of improving the safety systems through integration activities and utilization of good local and foreign experiences in the whole transport sector.
\end{abstract}

Keywords: transport accidents, transport safety systems

Streszczenie. Każdego dnia w systemie transportowym na świecie ginie ponad 3 tys. osób, z czego większość w wypadkach drogowych. Z punktu widzenia zarządzania bezpieczeństwem, każdy z systemów gałęziowych jest zorganizowany w inny sposób. Dotyczy to baz danych, instytucji zarządzających infrastrukturą transportowa i badających wypadki, systemów monitorujących ruch pojazdów, pociagów i statków. Pomimo wielu odrębności w funkcjonowaniu poszczególnych gałęzi transportu potencjalnie istnieją duże możliwości usprawnienia poszczególnych systemów bezpieczeństwa poprzez działania integracyjne i wykorzystanie dobrych doświadczeń krajowych i zagranicznych w całym sektorze transportu.

Słowa kluczowe: Wypadki transportowe, systemy bezpieczeństwa transportu 


\section{DIFFERENCES AND MUTUAL CONNECTIONS OF THE TRANSPORT SAFETY SYSTEMS}

\section{Introduction}

Transport system, apart from many internal connections, common objectives and economic tasks is diversified as regards to organization, technical factors, power absorbing ability and impact on the environment, health and human life. Each day in the world's transport system there are more than 3 thousand fatalities; and annual number of fatalities in the EU is approximately 50 thousand.

Transport system with a distinct domination of the motor transport has been shaped in the countries of Western Europe. Such a situation was influenced both by changes in the structure and size of the demand for the cargo transport, and transport policy mostly supporting road transport. Road transport includes almost $75 \%$ of all the cargo conveyance, and is distinguished by particularly high use of energy, pollutants emission and accident risk (table 1). Annually, 1.3 million fatalities worldwide are related to road transport. It does not mean, however, that the safety problem in other branches and means of transport characterized by relatively low number of accidents is a marginal problem. Due to the high transport volume of persons and cargo air crash, marine or train accident can mean both great amount of casualties and ecological catastrophe. In passenger transport, total socio-economical costs of sea, air and train accidents are scarce in relation to the costs of road accidents; however, when expressed per one fatality, the highest costs characterize water transport (table 2).

From the point of view of the risk management and using preventive and improvement measures, each of the sector safety systems has advantages which are worth to be spread on the whole transport system, but also obvious disadvantages which can be alleviated or eliminated with the help of experiences originated in other sectors. One can formulate a thesis that apart from many differences in the functioning of particular branches of transport, there are potentially big possibilities of improving the safety systems through integration activities and utilization of common achievements in order to improve the transport safety and particularly road transport safety. 
Table 1. Index of the fatalities in different mode of passenger transport in EU for the period 2001-2002 [1]

\begin{tabular}{|c|c|c|}
\hline \multirow[b]{2}{*}{ Mode of transport } & \multicolumn{2}{|c|}{ Fatalities index } \\
\hline & $\begin{array}{l}\text { per } 10^{8} \text { passenger } \\
\text { kilometre }\end{array}$ & $\begin{array}{l}\text { per } 10^{8} \text { passenger } \\
\text { kilometre }\end{array}$ \\
\hline Road transport & 0,95 & 28 \\
\hline including: motorcycle/bicycle & 13,8 & 440 \\
\hline on foot & 6,4 & 75 \\
\hline bicycle & 5,4 & 25 \\
\hline car & 0,7 & 25 \\
\hline bus and coach & 0,07 & 2 \\
\hline Passenger ferry & 0,25 & 16 \\
\hline Civil aviation & 0,035 & 8 \\
\hline Rail & 0,035 & 2 \\
\hline
\end{tabular}

Table 2. Costs of the accidents in different mode of transport in EU in 1995 [2]

\begin{tabular}{|lcc|}
\hline Mode of transport & $\begin{array}{c}\text { Total socio-economical costs } \\
\text { in million } €\end{array}$ & $\begin{array}{c}\text { Socio-economical costs per } \\
\text { one fatality } \\
\text { in billion } €\end{array}$ \\
\hline Roads & 162,00 & 3,6 \\
Railways & 2,74 & 2,1 \\
Aviation & 0,50 & 2,7 \\
Sea transport & 1,78 & 9,8 \\
\hline
\end{tabular}

\section{Transport accidents in Poland.}

Performing comparative analysis of the accidents in various branches of transport in Poland is limited not by the drawbacks of databases (incomplete DB's, scattering, inaccessibility) but rather by different definitions of the accidents and related terms. And so:

- road accident is defined as road event which is defined as a crash of at least two vehicles, hitting a pedestrian, another traffic participant or a person on the road, collision of a vehicle with an obstruction - which results in bodily harm infringing proper functioning of a human body, health problems of the person who did not cause the accident. Collision is defined as road event resulting in material losses only;

- rail accident is defined as unintended, sudden event or series of events involving a rail-vehicle, resulting in negative consequences for human health, possessions or environment; the accidents include: collisions, 
derailment, events on the railroad crossings, events involving individuals caused by rail-vehicle in motion, fire of a rail-vehicle. Serious accident is defined as an accident caused by collision, train derailment or similar event involving at least one fatality or at least five seriously injured persons, or causing serious damage of the rail-vehicle, infrastructure or environment evaluated for at least 2 million $€$ and having an obvious influence on the safety regulations on the railroad or on safety management;

- maritime accident is defined as event on the sea or linked water involving sinking or disappearance or losing a vessel in another way, abandoning ship, contact with the bottom, surface or underwater obstacle, crashing into a building structure, device or installation, which results in damages to the obstacles or the ship, fire or explosion of the vessel, contamination of the environment, endangering or limiting the safety of the vessel or its crew, disappearance of the man on board of the ship, death or injury of the human being in connection with their work or visit on board of the ship, the ship's behaviour, operation or state of the ship's devices or other elements or the properties of the cargo. Besides "Code for research of maritime catastrophes and accidents" lists the following terms: maritime catastrophe, very serious catastrophe, serious catastrophe as well as the list of their causes;

- air crash is defined as event connected with the exploitation of an airplane from the moment of boarding by the person intending to perform a flight, until the moment of disembarking all the persons on board, or event during the flight resulting in severe body harm of any person, damage or destruction of the airframe, airplane disappeared and was never found and official rescue mission was cancelled, or the aircraft was located in a place impossible to access. Air catastrophe is defined as air accident involving fatalities or disappearance of passengers, and those who sustained deadly injuries while onboard of the plane, resulting from direct contact with any element of the airplane, direct activity of the jet stream or disappearance of the airplane.

The above shows that the specific character of the operation of particular mode of transport influences the definitions of the accident, differently treating human and material losses as criteria of the accidents.

Statistics of the recorded transport accidents in Poland indicate evident domination of the road accidents, independently of the definition of the accident in particular branches of transport (fig. 1). Against the background of those road accidents, safety of the public transport (mainly municipal transport) looks advantageously. More reliable combination is the 
comparison of the number of fatalities. In maritime transport the number is close to zero (fig. 2). Relation between the number of the fatalities and the number of units in traffic (fig. 3) signals the necessity of performing more detailed analysis of the risk in particular branches of transport, considering similar exposure ratio (vehicle kilometres travelled, time of operating in the system). At the moment there is a lack of such information for all the transport branches analysed.

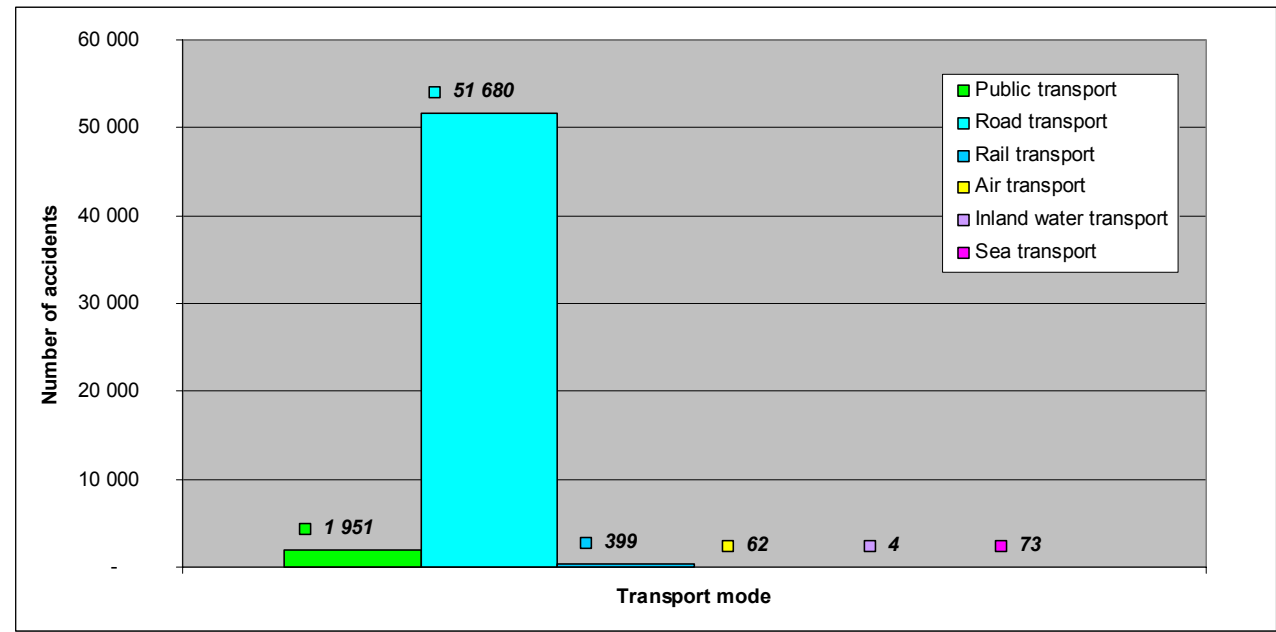

Figure 1 The average annual number of accidents in the branches of transport for the period 2001-2006 in Poland

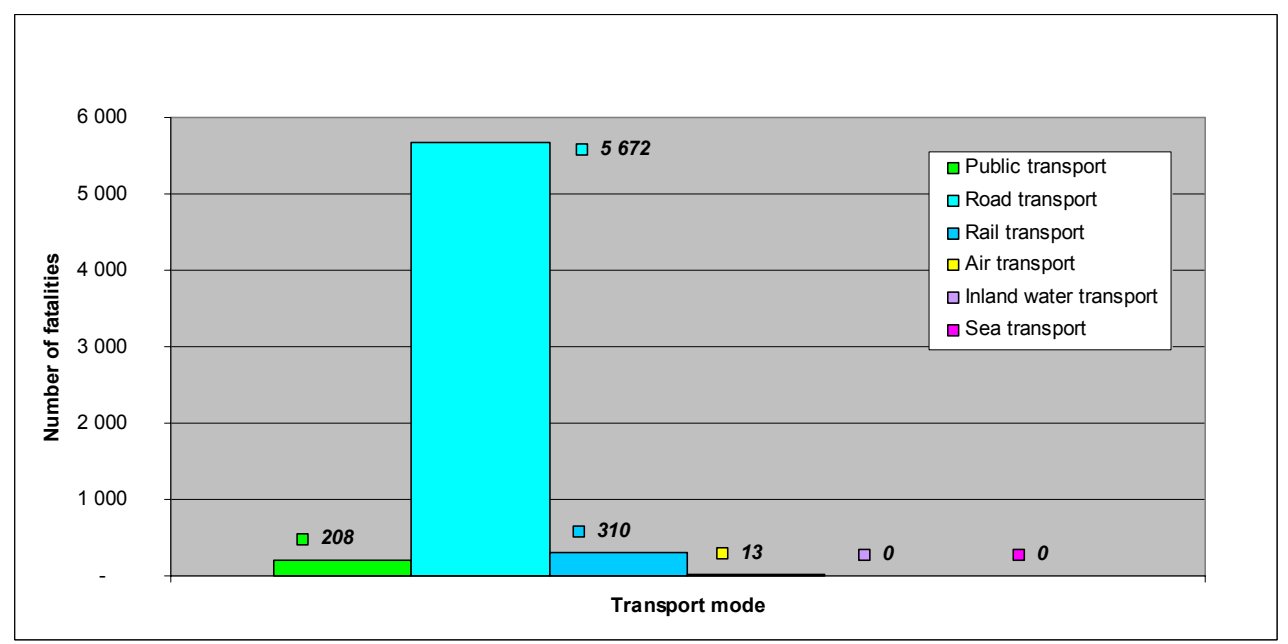

Figure 2 The average annual number of fatalities in the branches of transport for the period 2001-2006 in Poland. 


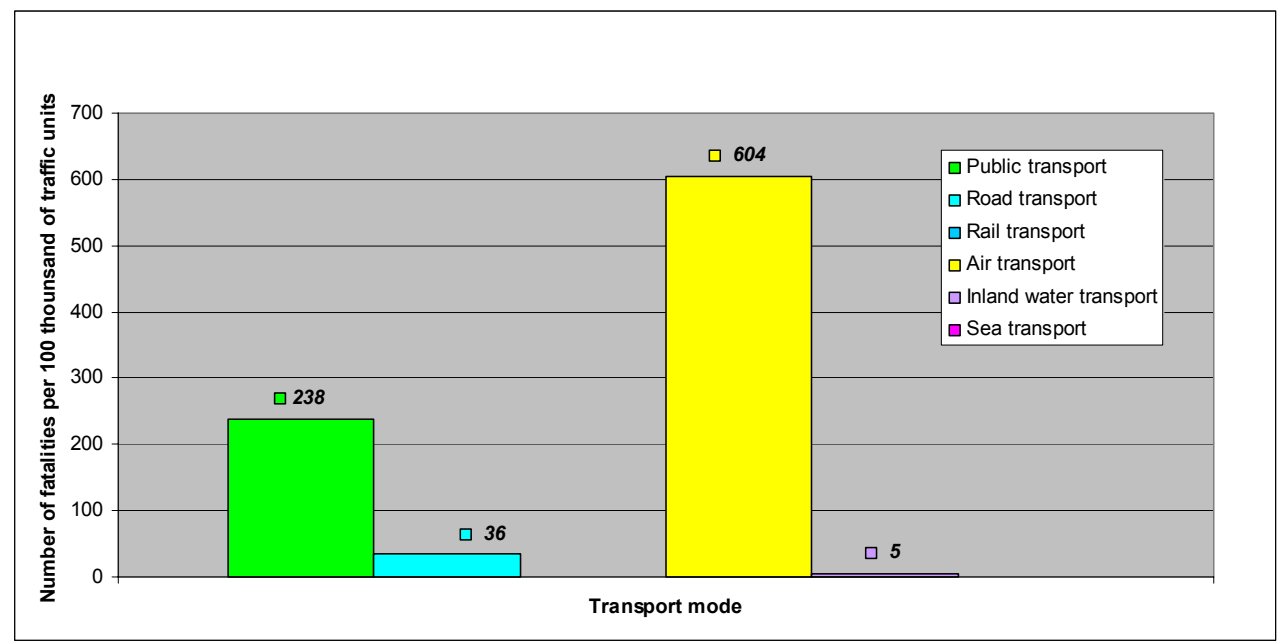

Figure 3 Average index of the fatalities per 100 thousand units in traffic in the branches of transport for the period 2001-2006 in Poland.

\section{Selected aspects of the safety systems organization in transport in Poland.}

In the comparative analyses of the functioning of branch transport safety systems it is possible to relate to many legal, organizational and financial aspects. From the point of view of the possibility of the integration of those systems it is necessary to identify the divergences and relations within the following aspects:

- institutional structures, their authority and relations,

- staff and its training system,

- safety monitoring system, quality of the data bases, data processing system and methods of the risk assessment,

- prevention system, methods of the running traffic management, introduced safety measures and control instruments used,

- rescue systems,

- scientific research of the safety,

- rules of planning of the safety improvements and funding of the systems' development.

Detailed analysis of these aspects, bearing in mind their further development is one of the basic tasks of the ZEUS Project [3]. ZEUS project's analyses performed to date indicate complete dissimilarity of the forms of transport management and division of the authority in the scope of safety in particular 
branches of transport. At the current stage there are quite small possibilities of integrated action (table 3). Similar situation occurs when accidents databases are concerned. Databases occur in diversified form, they have various content and purpose, and in case of air and marine transport they are dissipated.

It should, however, be emphasized that the systems of the air, maritime, and railway safety are closely connected with international law and are supervised by international safety agencies. The above concerns operating procedures, rescue systems, passing the traffic tests by vehicles and vessels, operators' training and licensing, etc. In the motor transport the range of the connections and international supervision is relatively small, considering the influence of this means of transport on the overall transport safety.

Table 3. Basic institutions of the transport safety management in Poland

\begin{tabular}{|c|c|c|}
\hline $\begin{array}{l}\text { Mode of } \\
\text { transport }\end{array}$ & $\begin{array}{l}\text { Supervising institutions } \\
\text { with } \\
\text { authority on the safety }\end{array}$ & $\begin{array}{c}\text { Specially designed institutions } \\
\text { with } \\
\text { authority on the safety only }\end{array}$ \\
\hline $\begin{array}{c}\text { Road } \\
\text { transport }\end{array}$ & $\begin{aligned} \text { - } & \text { Ministry of Transport } \\
\text { - } & \text { Police Headquarters } \\
\text { - } & \text { National Headquarters } \\
\text { - } & \text { Chief Inspectorate of the } \\
& \text { Road Transport } \\
\text { - } & \text { Regional Road Traffic Center } \\
- & \text { Road authorities } \\
\text { - } & \text { Public transport authorities }\end{aligned}$ & - National Road Safety Council \\
\hline $\begin{array}{c}\text { Rail } \\
\text { transport }\end{array}$ & $\begin{aligned} \text { - } & \text { Ministry of Transport } \\
\text { - } & \text { Office for Rail Transport } \\
\text { - } & \text { Chief Inspector of the Rail } \\
& \text { Technical Supervision }\end{aligned}$ & $\begin{array}{l}\text { - } \quad \text { State Commission for } \\
\text { Railway Accident } \\
\text { Investigation }\end{array}$ \\
\hline $\begin{array}{c}\text { Air } \\
\text { transport }\end{array}$ & $\begin{array}{l}\text { - Ministry of Transport } \\
\text { - Office for Civil Aviation }\end{array}$ & $\begin{array}{l}\text { - } \\
\text { State Commission for Air } \\
\text { Accident Investigation } \\
-\quad \text { Commission for Accident } \\
\text { Investigation of State } \\
\text { Aviation }\end{array}$ \\
\hline $\begin{array}{l}\text { Maritime } \\
\text { transport }\end{array}$ & $\begin{array}{l}\text { - Ministry of Transport } \\
\text { - Maritime Offices (with VTS } \\
\text { systems and Headquarters } \\
\text { and Control Centre of the } \\
\text { Maritime Administration) } \\
\text { - National Authority for the } \\
\text { Inland Water Management }\end{array}$ & $\begin{array}{ll}\text { - } & \text { Maritime Chamber } \\
\text { - } & \text { Maritime Service for Search } \\
& \text { and Rescue }\end{array}$ \\
\hline
\end{tabular}




\section{Conclusion}

Analyses of the existing safety systems indicate their great diversity in particular branches of transport. Searching for the new impulses for the improvement of the efficiency of the transport safety management there are potentially big possibilities resulting from the integration activities and utilization of the proven experiences within the transport sector. It is justified to take up research tasks within priorities seen from the point of view of the systems integration areas such as:

- institutional and legal system for the integrated transport safety systems,

- methods of the risk assessment in the transport systems (definitions, models, description methods, risk prediction and identification of the basic problems),

- system reacting towards the danger (online monitoring, supervision, rescue and damage removal),

- post-accident activity system (commissions, their working procedures, methods for the identification of the accidents' causes, treatment of injured, formulation of the post-accident recommendations).

\section{References:}

1. Transport safety performance in the EU. A statistical overview. European Transport Safety Council 2003

2. Transport accident costs and the value of safety. European Transport Safety Council 1997

3. Zintegrowany System Bezpieczeństwa Transportu ZEUS. (Integrated Transport Safety System) Research project ordered by PBZ 2/2006 www.projekt.e-zeus.eu 


\section{ODRĘBNOŚCI I WZAJEMNE POWIAZZANIA SYSTEMÓW BEZPIECZEŃSTWA TRANSPORTU}

\section{Wstęp}

System transportu, pomimo wielu wewnętrznych powiązań, wspólnych celów i zadań gospodarczych, jest zróżnicowany pod względem organizacyjnym i technicznym, chłonności energetycznej i oddziaływania na środowisko naturalne, życie i zdrowie człowieka. Każdego dnia w systemie transportowym na świecie ginie ponad 3 tys. osób, a w Unii Europejskiej roczna liczba ofiar śmiertelnych wynosi około 50 tysięcy.

W krajach Europy Zachodniej ukształtował się system transportowy o wyraźnej dominacji transportu samochodowego. Wpływ na to miały zarówno zmiany struktury i wielkości popytu na transport ładunków, jak i polityka transportowa wspierająca głównie rozwój transportu drogowy. Transport ten obejmuje prawie $75 \%$ wszystkich przewozów towarów i wyróżnia się szczególnie wysokim zużyciem energii, emisją zanieczyszczeń i zagrożeniem wypadkowym (tabela 1). Na świecie tylko $\mathrm{z}$ transportem drogowym związanych jest prawie 1,3 mln ofiar śmiertelnych rocznie. Nie oznacza to jednak, że problem bezpieczeństwa w innych gałęziach i rodzajach transportu charakteryzujących się stosunkowo niewielką liczbą wypadków jest problemem marginalnym. Wypadek statku powietrznego, statku morskiego czy pociąu przy ich dużej pojemności przewozowej osób i towarów może oznaczać zarówno dużą liczbę ofiar jak i katastrofę ekologiczną. W transporcie pasażerskim łączne koszty społeczno-ekonomiczne wypadków morskich, lotniczych i kolejowych są znikome w stosunku do kosztów wypadków drogowych, jednak $\mathrm{w}$ przeliczeniu na jedną ofiarę śmiertelną najwyższymi kosztami charakteryzuje się transport wodny (tabela 2).

$\mathrm{Z}$ punktu widzenia zarządzania ryzykiem oraz stosowania środków prewencyjnych i naprawczych każdy $\mathrm{z}$ sektorowych systemów bezpieczeństwa ma swoje silne strony warte rozpowszechnienia na cały system transportowy jak i ewidentnie słabe strony, które można łagodzić lub eliminować korzystając z doświadczeń innych sektorów. Można postawić tezę, że pomimo wielu odrębności w funkcjonowaniu poszczególnych gałęzi transportu istnieją potencjalnie duże możliwości usprawnienia systemów bezpieczeństwa poprzez działania integracyjne i wykorzystanie 
wspólnego dorobku, a przez to poprawę bezpieczeństwa transportu, zwłaszcza w transportu drogowego.

Tabela 1. Wskaźniki ofiar śmiertelnych $\mathrm{w}$ różnych rodzajach transportu pasażerskiego w UE-15 [1]

\begin{tabular}{|c|c|c|c|}
\hline \multirow{2}{*}{\multicolumn{2}{|c|}{ Rodzaj transportu }} & \multicolumn{2}{|c|}{ Wskaźnik ofiar śmiertelnych } \\
\hline & & na $10^{8}$ osobokilometrów & na $10^{8}$ osobogodzin \\
\hline \multicolumn{2}{|c|}{ Drogi samochodowe } & 0,95 & 28 \\
\hline \multirow[t]{5}{*}{ w tym: } & motocykl/motorower & 13,8 & 440 \\
\hline & pieszo & 6,4 & 75 \\
\hline & rower & 5,4 & 25 \\
\hline & samochód & 0,7 & 25 \\
\hline & autobus & 0,07 & 2 \\
\hline \multirow{2}{*}{\multicolumn{2}{|c|}{ Promy pasażerskie }} & 0,25 & 16 \\
\hline & & 0,035 & 8 \\
\hline \multicolumn{2}{|c|}{$\begin{array}{l}\text { Lotnictwo cywine } \\
\text { Koleje }\end{array}$} & 0,035 & 2 \\
\hline
\end{tabular}

Tabela 2. Koszty wypadków w różnych rodzajach transportu w UE w 1995 roku [2]

\begin{tabular}{|lcc|}
\hline Rodzaj transportu & $\begin{array}{c}\text { Łączne koszty społeczno- } \\
\text { ekonomiczne w mln Euro }\end{array}$ & $\begin{array}{c}\text { Koszty społeczno- } \\
\text { ekonomiczne przypadające } \\
\text { na jedną ofiare śmiertelną } \\
\text { w mld Euro }\end{array}$ \\
\hline Drogi & 162,00 & 3,6 \\
Koleje & 2,74 & 2,1 \\
Lotnictwo & 0,50 & 2,7 \\
Żegluga morska & 1,78 & 9,8 \\
\hline
\end{tabular}

\section{Wypadki transportowe w Polsce}

Ograniczeniem w prowadzeniu analizy porównawczej wypadków w różnych gałęziach transportu w Polsce są nie tyle mankamenty baz danych (niekompletność, rozproszenie, niedostępność), ale różne definicje wypadków i innych powiązanych w tym pojęć. I tak:

- wypadkiem drogowym jest zdarzenie drogowe polegające na zderzeniu, co najmniej dwóch pojazdów, potrąceniu pieszego, innego uczestnika ruchu lub innej osoby przebywającej na drodze, uderzeniu pojazdu $\mathrm{w}$ przeszkodę - wywołujących skutki w postaci uszkodzenia ciała naruszającego prawidłowe funkcjonowanie czynności organizmu, 
rozstroju zdrowia przez inną osobę niż sprawca; kolizja nazywamy zdarzenie drogowe, które pociągnęło za sobą tylko straty materialne;

- wypadek kolejowy jest to niezamierzone nagłe zdarzenie lub ciag takich zdarzeń $\mathrm{z}$ udziałem pojazdu kolejowego, powodujące negatywne konsekwencje dla zdrowia ludzkiego, mienia lub środowiska; do wypadków zalicza się w szczególności: kolizje, wykolejenia, zdarzenia na przejazdach, zdarzenia z udziałem osób spowodowane przez pojazd kolejowy będący $\mathrm{w}$ ruchu, pożar pojazdu kolejowego; poważny wypadek jest to wypadek spowodowany kolizją, wykolejeniem pociagu lub innym podobnym zdarzeniem z przynajmniej jedną ofiarą śmiertelną lub przynajmniej pięcioma ciężko rannymi lub powodujący znaczne zniszczenie pojazdu kolejowego, infrastruktury kolejowej lub środowiska, oszacowane na co najmniej 2 miliony euro i mający oczywisty wpływ na regulacje bezpieczeństwa kolei lub na zarządzanie bezpieczeństwem;

- wypadkami morskimi są zdarzenia na morzu lub wodach $\mathrm{z}$ nim połączonych, polegające na zatonięciu, zaginięciu lub utraceniu statku w inny sposób, opuszczeniu statku, zderzeniu statków, zetknięciu statku $\mathrm{z}$ dnem, podwodną lub nawodną przeszkodą, uderzeniu statku $\mathrm{w}$ budowlę, urządzenie lub instalację, w następstwie którego statek spowodował ich uszkodzenie lub doznał uszkodzenia, powstaniu pożaru lub wybuchu na statku, zanieczyszczeniu środowiska w następstwie utraty lub uszkodzenia statku, zagrożeniu albo ograniczeniu bezpieczeństwa statku lub znajdujących się na nim osób, zaginięciu człowieka przebywającego na statku, śmierci lub uszczerbku na zdrowiu człowieka w związku z pracą lub pobytem na statku, zachowaniem się statku, działaniem lub stanem jego urządzeń albo innych jego elementów lub właściwościami ładunku statku; poza tym „Kodeks postępowania badawczego dla katastrof i wypadków morskich" precyzuje pojęcia katastrofy morskiej, bardzo poważnej katastrofy, poważnej katastrofy i wypadku morskiego, a także wykaz głównych ich przyczyn;

- wypadek lotniczy jest to zdarzenie związane z eksploatacją statku powietrznego, które zaistniało od chwili, gdy jakakolwiek osoba weszła na jego pokład z zamiarem wykonania lotu, do chwili opuszczenia pokładu statku powietrznego przez wszystkie osoby znajdujące się na nim oraz podczas którego jakakolwiek osoba doznała co najmniej poważnych uszkodzeń ciała lub statek powietrzny został uszkodzony lub nastąpiło zniszczenie jego konstrukcji albo statek powietrzny zaginął $\mathrm{i}$ nie został odnaleziony, a urzędowe jego poszukiwania zostały odwołane 
lub statek powietrzny znajduje się w miejscu, do którego dostęp nie jest możliwy; katastrofa lotnicza to wypadek lotniczy z ofiarami ludzkimi w wyniku śmierci lub zaginięcia osób, które przebywały na pokładzie statku powietrznego, a także tych którzy odnieśli śmiertelne uszkodzenia ciała podczas przebywania na pokładzie statku powietrznego, w wyniku bezpośredniego kontaktu $\mathrm{Z}$ jakimkolwiek elementem statku powietrznego, bezpośredniego działania strumienia gazów silnika odrzutowego, zaginięcia statku powietrznego.

$\mathrm{Z}$ powyższego wynika, że specyfika funkcjonowania poszczególnych rodzajów transportu wpłynęła na odmienne zdefiniowanie zdarzenia wypadkowego, różnie traktując straty ludzkie i materialne jako kryteria wypadku.

Statystyki zarejestrowanych wypadków transportowych w Polsce wskazują na ewidentna dominacje wypadków drogowych, niezależnie od definicji wypadku w poszczególnych gałęziach transportu (rys. 1). Na tle tych wypadków drogowych korzystnie przedstawia się bezpieczeństwo transportu publicznego (głównie transportu miejskiego). Bardziej wiarygodnym zestawieniem jest porównanie liczb ofiar śmiertelnych. $\mathrm{W}$ transporcie wodnym liczba ta jest bliska zeru (rys. 2). Odniesienie liczby ofiar śmiertelnych do liczby jednostek ruchu (rys. 3) jest sygnałem do przeprowadzenia bardziej szczegółowej analizy ryzyka w poszczególnych gałęziach transportu $\mathrm{z}$ uwzględnieniem podobnych miar ekspozycji (pracy przewozowej, czasu przebywania w systemie).

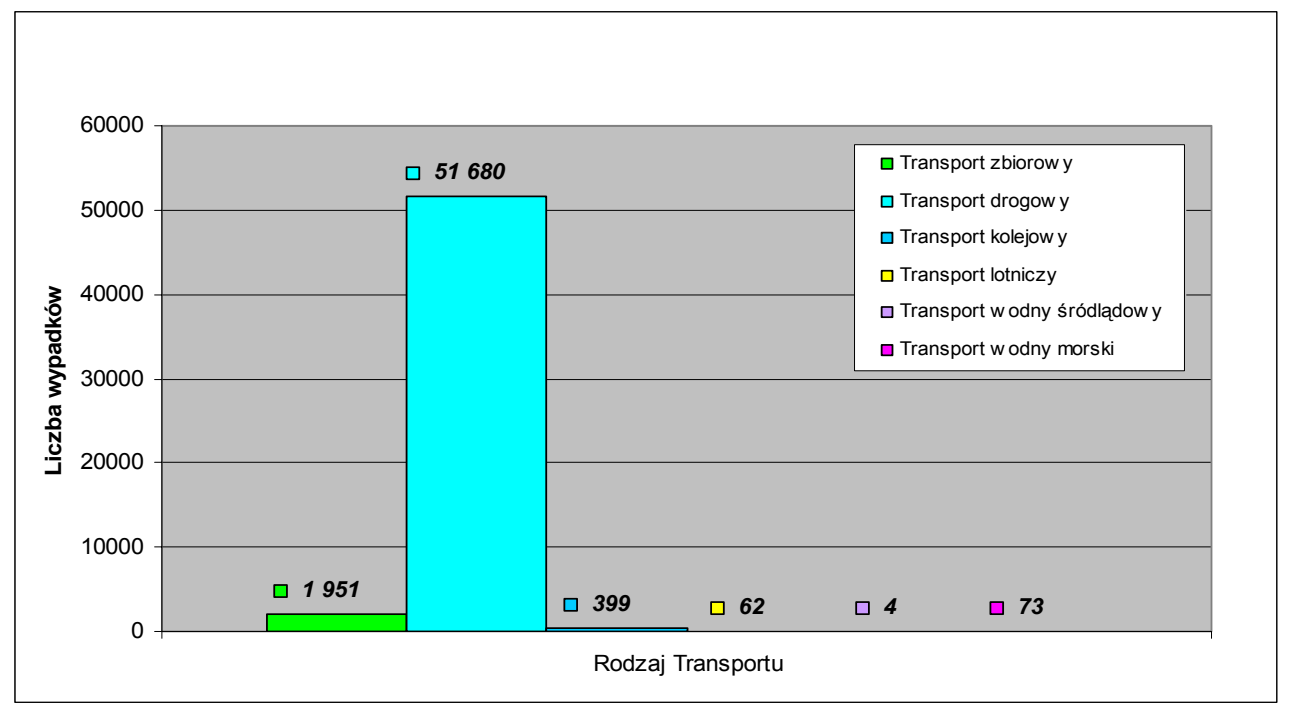

Rys. 1. Średnia roczna liczba wypadków w gałęziach transportu w okresie 2001-2006 w Polsce 


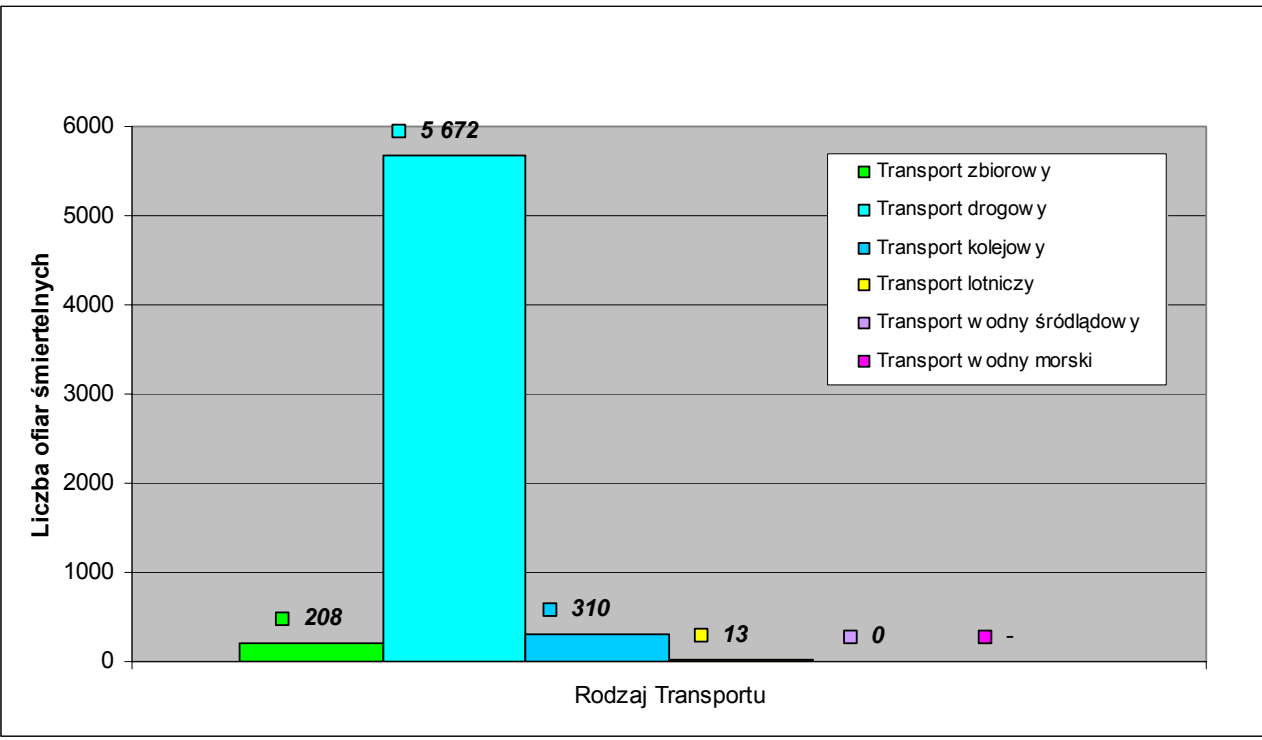

Rys. 2. Średnia roczna liczba ofiar śmiertelnych w gałęziach transportu w okresie 20012006 w Polsce

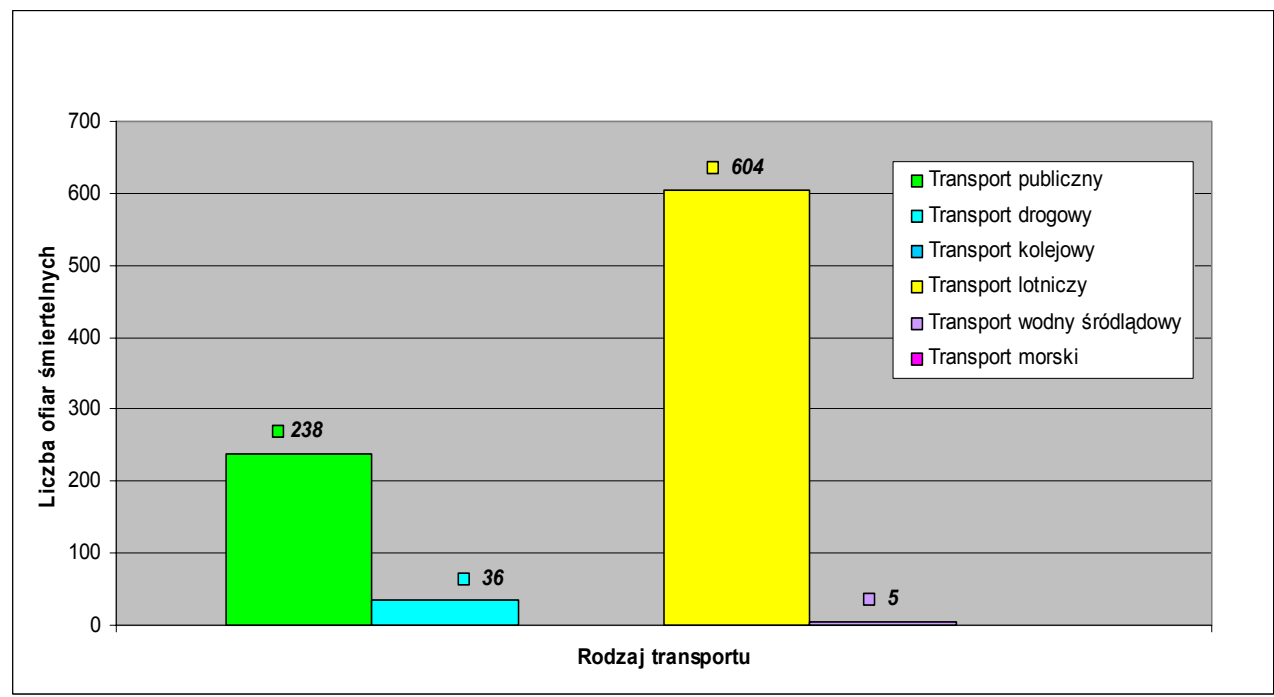

Rys. 3. Średni roczny wskaźnik ofiar śmiertelnych na 100 tys. jednostek ruchu w gałęziach transportu w okresie 2001-2006 w Polsce 
Obecnie w Polsce brak jest informacji na temat przebytej drogi lub łącznego czasu przemieszczania się środków transportu w analizowanych gałęziach transportu i ich segmentach przewozowych (przewozy pasażerskie, towarowe, cywilne, wojskowe itp.). W tym zakresie niezbędne jest przeprowadzenie specjalnych badań.

\section{Wybrane aspekty organizacji systemów bezpieczeństwa w gałęziach transportu w Polsce}

W analizach porównawczych funkcjonowania gałęziowych systemów bezpieczeństwa transportu możliwe jest odnoszenie się do wielu aspektów prawnych, organizacyjnych, finansowych. $Z$ punktu widzenia możliwości integracji tych systemów niezbędna jest identyfikacja odrębności i powiązań między innymi w zakresie:

- struktur instytucjonalnych, ich kompetencji, wzajemnych powiązań,

- kadr i systemu ich szkolenia,

- systemu monitoringu bezpieczeństwa, jakości baz danych, systemu przetwarzania danych i metod oceny ryzyka,

- systemu prewencji, metod bieżącego nadzoru nad ruchem, wdrażanych środki poprawy bezpieczeństwa, stosowanych instrumentów kontrolnych,

- systemu ratownictwa,

- badań naukowych w zakresie bezpieczeństwa,

- zasad programowania poprawy bezpieczeństwa i finansowania rozwoju systemów.

Szczegółowa analiza tym aspektów, także w pod kątem ich dalszego rozwoju jest jednym $\mathrm{z}$ podstawowych zadań Projektu ZEUS [3]. Dotychczasowe analizy wykonane w ramach Projektu ZEUS wskazują na całkowitą odmienność form zarządzania transportem i podziału kompetencji $\mathrm{w}$ zakresie bezpieczeństwa $\mathrm{w}$ poszczególnych gałęziach transportu i na obecnym etapie istnieją niewielkie możliwości działania zintegrowanego (tabela 3). Podobna sytuacja jest w bazach danych o wypadkach. Bazy te są mają różną formę, zawartość i przeznaczenie, a przypadku transportu lotniczego i wodnego są rozproszone.

Należy jednak podkreślić, że systemy bezpieczeństwa lotniczego, morskiego a także kolejowego działają $\mathrm{W}$ ścisłym powiązaniu $\mathrm{z}$ prawem międzynarodowym i nadzorowane są przez międzynarodowe agencje bezpieczeństwa. Dotyczy to procedur operacyjnych, systemów ratownictwa, dopuszczania pojazdów i statków do ruchu, szkolenia i licencjonowania 
operatorów itp. W transporcie samochodowym zakres tych powiązań i kontroli międzynarodowej jest stosunkowo niewielki, zważywszy wpływ tego transportu na bezpieczeństwo transportu.

Tabela 3. Podstawowe instytucje zarządzania bezpieczeństwem transportu w Polsce

\begin{tabular}{|c|c|c|}
\hline $\begin{array}{l}\text { Gałąź/rodzaj } \\
\text { transportu }\end{array}$ & $\begin{array}{c}\text { Instytucje nadzorujące } \mathrm{z} \\
\text { kompetencjami w zakresie } \\
\text { bezpieczeństwa }\end{array}$ & $\begin{array}{c}\text { Instytucje powołane tylko z } \\
\text { kompetencjami w zakresie } \\
\text { bezpieczeństwa }\end{array}$ \\
\hline $\begin{array}{l}\text { Transport } \\
\text { drogowy }\end{array}$ & $\begin{array}{ll}- & \text { Minister właściwy ds. } \\
\text { transportu } \\
-\quad \text { Komenda Główna Policji } \\
-\quad \text { Komenda Główna } \\
& \text { Państwowej Straży } \\
& \text { Pożarnej } \\
- & \text { Główny Inspektorat } \\
& \text { Transportu Drogowego } \\
- & \text { Wojewódzkie Ośrodki } \\
& \text { Ruchu Drogowego } \\
- & \text { Zarządy dróg } \\
- & \text { Zarządy transportu } \\
& \text { publicznego }\end{array}$ & $\begin{array}{l}\text { - } \text { Krajowa Rada } \\
\text { Bezpieczeństwa Ruchu } \\
\text { Drogowego }\end{array}$ \\
\hline $\begin{array}{l}\text { Transport } \\
\text { kolejowy }\end{array}$ & $\begin{array}{ll}- & \text { Minister właściwy ds. } \\
\text { transportu } \\
- & \text { Urząd Transportu } \\
\text { Kolejowego } \\
-\quad \text { Główny Inspektor } \\
\text { Kolejowego Dozoru } \\
\text { Technicznego }\end{array}$ & $\begin{array}{l}\text { - Państwowa Komisja Badania } \\
\text { Wypadków Kolejowych }\end{array}$ \\
\hline $\begin{array}{l}\text { Transport } \\
\text { lotniczy }\end{array}$ & $\begin{array}{ll}- & \text { Minister właściwy ds. } \\
\text { transportu } \\
-\quad \text { Urząd Lotnictwa } \\
\text { Cywilnego }\end{array}$ & 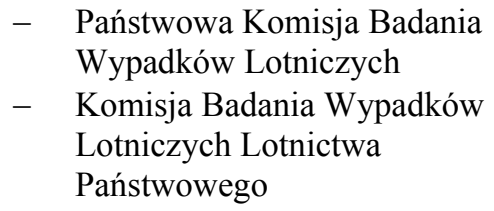 \\
\hline $\begin{array}{l}\text { Transport } \\
\text { wodny }\end{array}$ & $\begin{array}{ll}\text { - } & \text { Minister właściwy ds. } \\
\text { transportu } \\
\text { - } & \text { Urzędy Morskie - systemy } \\
\text { VTS, Centrum } \\
\text { Dyspozycyjno - Kontrolne } \\
\text { Administracji Morskiej } \\
\text { - } \quad \text { Krajowy Zarząd } \\
\text { Gospodarki Wodnej } \\
\end{array}$ & $\begin{array}{ll}\text { - } & \text { Izby Morskie } \\
\text { - } & \text { Morska Służba Poszukiwania } \\
& \text { i Ratownictwa }\end{array}$ \\
\hline
\end{tabular}




\section{Podsumowanie}

Analizy istniejących systemów bezpieczeństwa wskazują na duże ich zróżnicowanie w poszczególnych gałęziach transportu. Poszukując nowych impulsów dla poprawy skuteczności zarządzania bezpieczeństwem całego transportu istnieją potencjalnie duże możliwości wynikające $\mathrm{z}$ działań integracyjnych i korzystania ze sprawdzonych doświadczeń w ramach sektora transportu. Celowe jest podjęcie zadań badawczych w kilku priorytetowych $\mathrm{z}$ punktu widzenia integracji systemów obszarach, do których zaliczyć można:

- system instytucjonalno-prawny dla zintegrowanych systemów bezpieczeństwa transportu,

- metody ocen ryzyka w systemie transportu (definicje, modele, metody dla opisu zjawiska, predykcji ryzyka, identyfikacji podstawowych problemów),

- system reagowania na pojawienie się zagrożenia (monitoring on-line, nadzór, ratownictwo, usuwanie szkód),

- system działań powypadkowych (komisje i procedury ich działania, metody dla identyfikacji przyczyn wypadków, opieka nad poszkodowanymi, formułowanie rekomendacji powypadkowych).

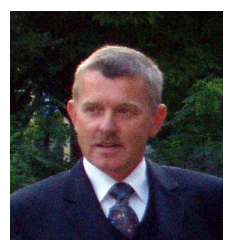

PhD Eng. Lech Michalski, Gdańsk University of Technology, Highway Engineering Department, specialisation: traffic engineering, road safety, transport planning 